\title{
REGUŁY UŻYCIA WYRAŻEŃ I NORMATYWNOŚĆ ZNACZENIA
}

\begin{abstract}
Streszczenie. Rozważania podjęte w tym artykule nawiązują do współczesnej dyskusji o normatywności znaczenia, jaka została zapoczątkowana przez S. Kripkego. Główny nurt tej dyskusji dotyczy związku normatywności znaczenia z poprawnością użycia wyrażeń i pozostawia problem rozumienia samej normatywności na boku. W tym artykule podjęta zostanie próba odpowiedzi na takie pytania, jak: Na czym polega normatywność reguł znaczeniowych? Jak rozumieć normy i co je wyróżnia spośród innych reguł? Do jakich racji można odwołać się w uzasadnieniu normatywności znaczenia?

W niniejszym artykule, jako punkt wyjścia, została krótko przedstawiona teza Kripkego o normatywności znaczenia oraz dominująca linia dyskusji dotyczącej tej tezy. Zostały pokazane trudności związane ze sformułowaniem kryterium poprawnego użycia, oraz wskazane, że istnienie reguł użycia wyrażeń nie jest jednoznaczne z normatywnością tych reguł. Podjęta została próba wskazania podstawowej charakterystyki znaczeń terminów „reguły” i „normy”, a następnie została omówiona kwestia społecznej determinacji reguł znaczeniowych. Zostało pokazane, że reguły użycia wyrażeń są zakotwiczone w społecznej funkcji języka. Na koniec została poruszona kwestia związku społecznie ugruntowanych reguł użycia wyrażeń z funkcją reprezentacji w języku świata pozajęzykowego.

Znaczenie rozumiane jako treść wyrażenia nie jest tylko konwencjonalne, ale jest też konstytuowane przez reprezentatywną funkcję języka. Zostało wskazane, aby normatywność znaczenia rozpatrywać w dwu wymiarach: społecznym, konwencjonalnym oraz drugim związanym z funkcją reprezentacji świata w języku.
\end{abstract}

Słowa kluczowe: znaczenie, reguły, normy, konwencje, normatywność, użycie wyrażeń.

1. Wstęp. 2. Normatywność znaczenia. Obrona i krytyka. 3. Reguły i normy. Potrzeba uściślenia pojęć. 4. Społeczny charakter reguł znaczeniowych. Konwencje i normy. 5. Znaczenie językowe a konwencje i normy. 6. Dwa uwarunkowania normatywności znaczenia. 7. Zakończenie.

\section{WSTĘP}

Współczesna dyskusja o normatywności znaczenia została zapoczątkowana pracą S. Kripkego z 1982 r. Kripke analizuje w niej relację pomiędzy znaczeniem a użyciem wyrażeń opisaną przez 
L. Wittgensteina w Dociekaniach flozoficznych i wysuwa tezę, że znaczenie wyrażeń ma charakter normatywny w stosunku do sposobów ich użycia ${ }^{1}$. Użyciem wyrażeń kierują reguły wyznaczone przez znaczenia, a nie dyspozycje mówiącego lub wcześniejsze fakty użycia. Reguły te określają, jak wyrażenie powinno być stosowane, niezależnie od intencji poszczególnych użytkowników. Istnienie takich reguł pozwala kwalifikować użycia wyrażeń jako poprawne i niepoprawne. Kripke uznaje normatywność znaczenia za jego istotną i wewnętrzną cechę.

Przyjęcie lub odrzucenie tezy o normatywności znaczenia ma swoje konsekwencje zarówno dla rozumienia znaczenia, jak i dla całej teorii języka. Teza, że użycie znaczących terminów jest działaniem zgodnym $\mathrm{z}$ regułami ukonstytuowanymi pierwotnie $\mathrm{w}$ stosunku do tego użycia, jest w opozycji do teorii, które przyjmują, że znaczenie jest określone przez faktyczne użycie terminu i determinowane przez czynniki pragmatyczne.

Dotychczasowa dyskusja koncentruje się głównie na zagadnieniu związku normatywności znaczenia z poprawnością użycia wyrażeń, na boku pozostawiając problem rozumienia samej normatywności i uzasadnienia uznawania, dlaczego występowanie reguł poprawnego użycia wyrażeń ma świadczyć o normatywności znaczenia. W tym artykule zostanie podjęty ten właśnie, nieco pomijany wątek rozważań. Podniesione zostaną następujące kwestie: co to znaczy, że jakieś reguły są normatywne, jak rozumieć normy i czym wyróżniają się one spośród innych reguł, jakiego rodzaju regułami są reguły użycia wyrażeń i co uzasadnia ich normatywność.

Sam język nie dostarcza podstaw do wyraźnego rozróżnienia pojęć reguty i normy. Dlatego dla odpowiedzi na pytanie, czy reguły użycia

1 Jest to praca S. Kripkego, Wittgenstein on Rules and Private Language z 1982. Jej polskie wydanie: S. Kripke, Wittgenstein o regułach i języku prywatnym, tłum. z ang. K. Posłajko, L. Wroński, Aletheia, Warszawa 2007. 
wyrażeń są normami, potrzebne jest wypracowanie dodatkowych kryteriów odróżnienia reguł od norm.

Pojęcie normatywności odnoszone było tradycyjnie do dziedziny prawa i moralności, jednak w ostatnich dekadach zyskało szeroki zakres nowych odniesień, jednocześnie tracąc na precyzji i jasności. Normatywność zaczęła być pojmowana jako powszechna własność wielu aspektów ludzkich działań (moralnych, prawnych, poznawczych, społecznych, językowych itp.). Tak szeroko rozumiana normatywność „przejawia się w zdolności do ustanawiania norm” ${ }^{2}$. Niektóre pojęcia, takie jak np. piękno, cnota, sprawiedliwość, odnoszą do pewnych standardów. Standardy te nie są tylko opisami optymalnego stanu, ale zobowiązują do postępowania zgodnego z tymi standardami. Normy nakazują, mówią jak należy postąpić, a nie tylko jak się zazwyczaj postępuje ${ }^{3}$.

Kiedy jednak należy mówić o regułach, a kiedy o normach? Samo sformułowanie reguł kierujących jakimś postępowaniem nie jest tym samym, co istnienie norm dla tego postępowania. Co przemawia za tym, że reguły znaczeniowe są normami? Kripke sformułował tezę o normatywności znaczenia, pozostawiając otwartymi kwestie dotyczące tego, czym są reguły znaczeniowe i jakie jest źródło ich normatywnego charakteru.

W niniejszym artykule zostanie, na wstępie, przedstawiona pokrótce ogólna teza Kripkego oraz dominująca linia krytyki i obrony jego tezy o normatywności znaczenia, jaka toczy się obecnie w filozofii języka. Następnie zostaną omówione różne rozumienia terminów „reguly” i „normy” pojawiające się w dyskusji nad normatywnością znaczenia i podjęta będzie próba wskazania różnicy pomiędzy regułami, które nie są normatywne, i normami. Następnie zostanie

2 B. Brożek, Pojęcie normatywności, w: Fenomen normatywności, red. A. Brożek, B. Brożek, J. Stelmach, Copernicus Center Press, Kraków 2013, 20.

3 Ch. M. Korsgaard, The Sources of Normativity, Cambridge Univesity Press, Cambridge 1996, 22. 
omówiona kwestia społecznej determinacji reguł znaczeniowych i próby uzasadnienia ich normatywnego charakteru, odwołujące się do społecznej funkcji języka. Na koniec zostanie wskazane, że normatywność znaczenia należy rozpatrywać w dwu wymiarach: społecznym oraz związanym z funkcją językowej reprezentacji świata.

\section{NORMATYWNOŚĆ ZNACZENIA. OBRONA I KRYTYKA}

Panuje zgoda co do tego, że normatywny charakter znaczenia przejawia się w tym, że znaczące wyrażenia mogą być poprawnie lub niepoprawnie użyte. Znaczenie wyrażeń określa reguły ich poprawnego użycia. Kripke przypisuje regułom użycia charakter preskryptywny, który jego zdaniem nierozerwalnie łączy się z normatywnością. Reguły określają jak powinno się używać wyrażeń, dostarczają kryterium kwalifikacji użycia, jako poprawnego lub nie.

Reguły użycia wyrażeń dla języka naturalnego nie są jawnie sformułowane. Są one zawarte implicite w znaczeniach wyrażeń. Znajomość znaczenia danego terminu polega, zdaniem Kripkego, na uchwyceniu reguł jego poprawnego stosowania. Ponieważ mogą zdarzać się błędy i pomyłki, nie chodzi o poszczególne fakty użycia, ale o istnienie kryterium pozwalającego na klasyfikację użycia wyrażenia na zgodnie i niezgodnie ze znaczeniem.

Jawne sformułowanie kryterium poprawnego użycia dostarcza poważnych trudności. Jeden $z$ bardziej popularnych i szerzej dyskutowanych sposobów sformułowania kryterium poprawności użycia wyrażeń pochodzi z pracy P. Boghossiana ${ }^{4}$. Autor formułuje zasadę poprawności użycia terminu ,zielony' i uogólnia ją na inne wyrażenia. Mówi, że jeśli wyrażenie ,zielony' znaczy zielony, to wyrażenie ,zielony' stosuje się poprawnie do rzeczy, które są zielone i niepoprawnie do takich, które nie są zielone. Idea ta stała się wzorem dla sformułowania ogólnego kryterium poprawności użycia wyrażeń.

4 P. Boghossian, The The Rule-Following Considerations, Mind 98(1989), 513. 
Fakt, że wyrażenie coś znaczy, pociąga za sobą, iż może być ono poprawnie odnoszone do jednych rzeczy i niepoprawnie do innych. Teza o normatywności znaczenia, zdaniem Boghossiana, zdaje po prostu sprawę, ze znanego faktu, że znaczące wyrażenia mają warunki poprawnego użycia ${ }^{5}$. Zostały jednak wysunięte wątpliwości, czy ta reguła ujmuje podstawową intuicję odnośnie do poprawności zastosowania terminu ,zielony', jak i innych wyrażeń.

W późniejszych pracach Boghossian rozwija pogląd, że samo istnienie reguł poprawnego użycia wyrażeń nie stanowi wystarczającego argumentu za tym, że znaczenie jest normatywne w sposób istotny, czyli wewnętrzny ${ }^{6}$. Reguly są wewnętrznie, czyli istotnie normatywne, zdaniem Boghossiana, gdy zobowiązanie do ich przestrzegania wynika $\mathrm{z}$ samego faktu ich istnienia, tak jak np. $\mathrm{z}$ faktu istnienia norm moralnego postępowania wynika zobowiązanie do ich przestrzegania. $Z$ samego istnienia warunku poprawności użycia wyrażenia nie wynika jeszcze, że powinno się używać wyrażeń poprawnie. Zobowiązanie do poprawnego użycia wyrażenia nie wynika ze znaczenia, lecz jest warunkiem zewnętrznym w stosunku do znaczenia. W wypadku wewnętrznej normatywności powinność, zobowiązanie jest cechą konstytutywną. W tym sensie, zdaniem Boghossiana, normatywne są zasady moralne, znaczenie natomiast nie jest wewnętrznie normatywne, Normatywność znaczenia określa Boghossian jako warunkową, gdyż takiego rodzaju jest powinność poprawnego użycia wyrażeń. Jeśli ktoś chce posługiwać się poprawie danym językiem, powinien używać wyrażeń zgodnie z ich znaczeniami?

Kryterium poprawnego użycia wyrażeń w sformułowaniu Boghossiana jest najbardziej rozpowszechnione i w dalszych dyskusjach

5 Tamże.

6 P. Boghossian, Is Meaning Normative?, w: Philosophy - Science -Scientific Philosophy. Main Lectures and Colloquia of GAP. 5, Fifth International Congress of the Society for Analytical Philosophy, red. Ch. Nimtz, A. Beckermann, Mentiz, Paderborn 2003, 212.

7 Tamże, 212. 
(Boghossian, Whiting ${ }^{8}$ i Hattiangadi ${ }^{9}$ ) przybiera postać, jaką nadaje mu Whiting:

(1) w znaczy $\mathrm{F} \rightarrow(x)$ (w stosuje się poprawnie do $x \leftrightarrow x$ jest $f)^{10}$,

gdzie $w$ jest terminem, $F$ jego znaczeniem, a $f$ własnością, ze względu na którą $w$ stosuje się do $x$.

Takie sformułowanie warunku poprawności użycia ma konsekwencje, które trudno przyjąć. Np. należałoby uważać, że jeśli termin ,zielony' w języku polskim znaczy zielony, to poprawnie używa się go tylko w wypadku, gdy stosujemy go do orzekania zieloności o rzeczy zielonej. Tak sformułowaną regułę poprawnego użycia, trudno też zastosować.

Jak wskazuje Hattiangadi, powyższe sformułowanie warunku poprawności wyraża równoważność warunku poprawności użycia: w stosuje się poprawnie do $x$, i stwierdzenia prawdziwości orzekania: fjest prawdziwe o $x$. Zdania normatywne o warunkach poprawności użycia wyrażeń stają się zdaniami o faktach wyrażonych przez schemat: $x$ jest $f$. Poprawność użycia staje się warunkiem mówienia prawdy. Zobowiązanie do mówienia prawdy nie wynika jednak z reguł znaczeniowych. Zdaniem Hattiangadi, trudności ze sformułowaniem warunku poprawności użycia wyrażeń wolnego od powyższych zarzutów są argumentem na rzecz odrzucenia tezy o normatywności znaczenia. Znaczenie wyrażenia nie może obligować do mówienia prawdy. Powinność mówienia prawdy wynikać może raczej z normy moralnej niż semantycznej.

Rozpatrywane sformułowanie przysparza także dalszych kłopotów, nie bierze ono pod uwagę na przykład intencji mówienia

8 D. Whiting, The Normativity of Meaning Defended, Analysis 67(2007)2,133-140,wersja on line: DOI:10.1111/j.1467-8284.2007.00663.x

9 A. Hattiangadi, Some more thoughts on semantic oughts: a reply to Daniel Whiting, Analisys 69( 2009)1, 54-63.

10 D. Whiting, dz. cyt., 3. 
nieprawdy, nie rozróżnia niepoprawnego użycia od pomyłki co do faktów, nie uwzględnia wypadku formułowania wyrażeń innych niż zdania opisowe typu: $x$ jest $f$.

Kolejnym poważnym zarzutem wysuwanym przeciwko omawianemu kryterium jest, zdaniem Hattiangadi, fakt, iż jest ono zdaniem opisowym, a nie preskryptywnym, nie formułuje powinności, a jedynie klasyfikuje konkretne użycia jako poprawne lub nie ${ }^{11}$.

D. Whiting, broniąc tezy o normatywności znaczenia, twierdzi, że reguła, która wskazuje standardy poprawnego użycia, może mieć postać deskryptywną. Opisuje ona standard, a przez to ustanawia normę, czyli określa, jak słowa powinny lub mogą być używane w poprawny sposób. Opisowa formuła (1), która określa standard poprawnego użycia, może być, zdaniem Whitinga, łatwo przeformułowana w terminach powinności lub możliwości, które są uznawane za warunek normatywności ${ }^{12}$. Hattiangadi odrzuca jednak jego sformułowanie kryterium (1) w formie normatywnej w postaci:

(2) w znaczy $F \rightarrow(x)$ (w powinno być zastosowane do $x \leftrightarrow x$ jest $f)^{13}$.

Autorka zauważa, że również to sformułowanie wyraża raczej powinność mówienia prawdy niż warunek poprawnego użycia wyrażeń. Sformułowanie (2) nie jest, zdaniem Hattiangadi, równoważne sformułowaniu (1). Brak uzasadnienia dla przejścia od formuły (1) do formuly (2) jest jej zdaniem kolejnym argumentem przeciw tezie o normatywności znaczenia. Kryterium poprawności użycia wyrażeń nie formułuje powinności poprawnego ich używania ${ }^{14}$.

Przytoczone elementy dyskusji odnośnie do normatywności znaczenia pokazują, że koncentruje się ona głównie na zagadnieniu

11 A. Hattiangadi, Is meaning normative?, Mind and Language 21(2006), 224.

12 D. Whiting, dz. cyt., 6-7.

13 Tamże, 6.

14 A. Hattiangadi, Some more thoughts on semantic oughts, dz. cyt., 55-56. 
kryterium poprawnego użycia wyrażeń. Milcząco zostało przyjęte założenie, że występowanie takiego kryterium jest argumentem na rzecz tezy o normatywności znaczenia. Jest to jednak tylko pewien fragment problematyki. Należy bowiem, obok kwestii samego sformułowania kryterium poprawnego użycia wyrażenia (dla którego formuła (1) wydaje się nieadekwatna), rozważyć także kwestię, na jakiej podstawie istnienie reguł poprawnego użycia ma świadczyć o normatywności znaczenia. Skąd reguły użycia wyrażeń czerpią swój normatywny charakter? Ze względu na co jakiekolwiek reguły uznaje się za normatywne? Dla Hattiangadi decydujący jest ich preskryptywny charakter, dla Boghossiana najważniejsza jest zdolność reguły do formułowania zobowiązania, a dla Whitinga formułowanie standardu. Dopóki nie określi się, ze względu na co reguły uznawane są za normatywne, poszczególne głosy w dyskusji będą dotyczyć różnych kwestii.

\section{REGUŁY I NORMY. POTRZEBA UŚCIŚLENIA POJĘĆ}

Przytoczone powyżej dyskusje odnośnie do normatywności reguł użycia wyrażeń, wskazują na potrzebę rozważenia kwestii, jakie cechy decydują, że jakieś reguły są normatywne. Dla ustalenia czy znaczenie językowe jest normatywne, ważne jest wskazanie różnicy pomiędzy regułami, które nie są normami (dalej są regułami nienormatywnymi) i regułami, które są normatywne (dalej są normami). To, czy ktoś przyjmuje tezę o normatywności znaczenia, czy ją odrzuca, zależy w znacznym stopniu od tego, jak rozumiane jest samo pojęcie normy.

Język naturalny nie dostarcza wystarczająco precyzyjnego rozróżnienia pojęć „reguły” i „normy”. Pojęcia te występują w wielu językach specjalistycznych, gdzie mają one swoje definicje. Pojęcia te występują w prawie, etyce, logice, matematyce, naukach przyrodniczych i technicznych itd. Jednak przyjęte tam sposoby rozumienia i formułowane definicje zarówno norm, jak i reguł są zawężone do zakresu konkretnej problematyki czy teorii. Nie formułują one 
jakiegoś uniwersalnego kryterium dla wskazania różnicy pomiędzy znaczeniem terminów „reguła” $i$,norma”, które nie byłoby arbitralne.

Ważnym elementem dyskusji o normatywności znaczenia jest zatem bardziej szczegółowe rozważenie tego, co konstytuuje normy lub normatywny charakter reguł. Dopiero na gruncie tych rozważań można powiedzieć, czy reguły użycia wyrażeń spełniają warunki bycia normą czy też nie. Takie ustalenie zawiera jednak pewien element arbitralnej decyzji. Język prawniczy i język etyki dostarczają wielu różnych sposobów rozumienia pojęcia normy, ale nie jest oczywiste posłużenie się którymś $\mathrm{z}$ takich określeń $\mathrm{w}$ odniesieniu do normatywności znaczenia.

W dyskusji nad normatywnością znaczenia językowego pojawiło się kilka prób wskazania różnicy pomiędzy regułą i normą. Za paradygmatyczne przypadki norm bezspornie uznaje się normy moralne i normy prawne. Mówi się jednak nie tylko o normach moralnych i prawnych, ale także o normach społecznych, obyczajowych, normach technicznych itp. Pojęcie normy jest nie tylko szeroko i różnorodnie stosowane, jest też wieloznaczne i rozmyte. $Z$ drugiej strony pojęcie reguły ma jeszcze bardziej szeroki zakres stosowania i odnoszone jest do różnego typu ustalonych wzorów zachowań ludzkich i innych prawidłowości.

P. Boghossian w artykule Rules, Norms and Principles: A Conceptual Framerwork ${ }^{15}$ zauważa, że choć język potoczny nie daje podstawy do wyraźnego odróżnienia pomiędzy znaczeniami terminów reguły i normy, to pojęcie reguły ma szersze i bardziej ogólne znaczenie niż pojęcie normy. Normy, jego zdaniem, stanowią szczególną grupę reguł. Zatem normy posiadają ogólne własności reguł i wykazują dodatkowe cechy, które wyróżniają je na tle innych reguł. Twierdzi, że znaczenie generuje reguły użycia, ale reguły te nie są normatywne.

15 P. Boghossian, Rules, Norms and Principles: A Conceptual Framework, w: Problems of Normativity, Rules and Rule-Following, red. M. Araszkiewicz, P. Banaś, T. Gizbert-Studnicki, K. Płeszka, Springer, Franfurt a. M.-London-New York, 2014, 3-11. 
Jak twierdzi sam autor, nie są one normatywne w interesującym, istotnym sensie.

Reguły to ustalone wzorce, standardy, które kierują naszym zachowaniem w ten sposób, że określają, jakie zachowanie jest oczekiwane, pożądane, zachowujące standardy itp., które mogą być zachowane lub nie w poszczególnych wypadkach. F. Peter i K. Spiekermann wskazują, że reguły mogą być złamane, postąpienie niezgodnie z regułą jest dopuszczalne. Właśnie ze względu na tę dopuszczalność złamania wzorów ludzkich zachowań w pojedynczych wypadkach, reguły tych zachowań cechuje element preskryptywny, mówią one, jakie zachowanie powinno być, aby pozostawać w zgodzie z regułą, nie zaś, jakie faktycznie ono jest czy będzie ${ }^{16}$. Paradygmatycznymi przykładami reguł są np. reguły gry w szachy (lub innej gry) lub reguły etykiety. Zatem wszelka reguła, dopuszczając możliwość jej złamania jednocześnie formułuje, jakie warunki powinno spełniać zachowanie, aby było uznane za zgodne z nią. Nie narzuca jednak samej powinności przestrzegania reguły. Istnienie warunków zgodności postępowania zgodnego $\mathrm{z}$ regułą nie jest, zdaniem Hattiangadi ${ }^{17}$, tym samym, co powinność zachowania zgodnego $\mathrm{z}$ regułą. Uznaje ona preskryptywność, rozumianą jako powinność postępowania zgodnego $\mathrm{z}$ regułą, za istotną cechę dla normatywnego charakteru reguły. Inaczej jednak niż Kripke pojmuje ową preskryptywność, której nie łączy z samym faktem formułowania przez regułę standardów zachowania (np. poprawnego użycia) i powinnością zachowania tych warunków w celu pozostania w zgodzie $\mathrm{z}$ regułą, ale z powinnością wyboru i przestrzegania danej reguły jako takiej.

Podobnie, zdaniem Boghossiana, normy to standardy zachowań, których powinno się przestrzegać ze względu na sformułowaną

16 F. Peter, K. Spiekermann, Rules, Norms and Commitments, w: The Sage Handbook of The Philosophy of Social Science, red. I.C Jarvie, J. Zamora-Bonilla, Sage, London, 217-239.

17 A. Hattiangadi, Oughts and Thoughts: Rule-Following and the Normativity of Content, Oxford University Press, Oxford 2007 oraz A. Hattiangadi, Some more thoughts on semantic oughts, dz. cyt. 
w nich powinność, a za których złamanie grożą sankcje lub krytyka. $\mathrm{Z}$ normą związana jest powinność w sensie zobowiązania nałożonego na podejmującego rodzaj działania określony normą.

Reguły mogą mieć charakter empiryczny lub normatywny. Stwierdzają jak zazwyczaj postępuje się w danej sytuacji, czyli mają charakter opisu ustalonego sposobu postępowania lub określają jak powinno się postępować, czyli formułują pewną instrukcję. Mogą one przybierać formę zdań normatywnych, w których występują zwroty takie, jak: może, musi, powinien itp. Takie zdania, zdaniem Boghossiana, można przeformułować na zdania opisowe, o tej samej treści propozycjonalnej. Np. zdanie normatywne: Jeśli ktoś jest przestępcą, to powinien podlegać karze', łatwo przeformułować na zdanie: ,Jeśli ktoś jest przestępcą to podlega karze'.

Reguły, zdaniem Boghossiana ${ }^{18}$, są bytami abstrakcyjnymi, jak liczby, własności, sądy. Przyjęcie reguł polega na przyjęciu pewnej treści intencjonalnej. To przyjęcie nie zawsze jest równoważne $\mathrm{z}$ akceptacją reguł przez osoby zobowiązane do ich przestrzegania. Zobowiązanie do postępowania zgodnie $\mathrm{z}$ regułą nie jest zawsze powiązane ściśle $\mathrm{z}$ ich akceptacją, tak jak jest powiązane $\mathrm{z}$ przyjęciem ich treści. Fakt akceptacji nie jest, zdaniem autora, konstytutywny dla bycia regułą. Jednak w wypadku reguły fakt akceptacji leży u podstawy postępowania zgodnego $\mathrm{z}$ regułą.

Normy moralne są, według Boghossiana, niezależne od akceptacji jednostki lub społeczeństwa. Ich treść zobowiązuje do ich przestrzegania bez względu na nic innego. Reguły zależne od akceptacji czerpią swoją normatywność $\mathrm{z}$ aktu akceptacji, dlatego nie są wewnętrznie normatywne ${ }^{19}$. Reguły, np. etykiety, są zależne od akceptacji społecznej i dlatego nie obowiązują powszechnie, a tylko $\mathrm{w}$ danej grupie, podobnie jak reguły prawne, które są zależne od

18 P. Boghossian, Rules, Norms and Principles, dz. cyt., 4.

19 Tamże, 11. 
przyjęcia przez legislatora i też odnoszą się tylko do grupy, w której dane prawo obowiązuje.

Kierowanie się regułami przez członków danej grupy nie jest jeszcze warunkiem wystarczającym dla uznania ich normatywności. Według Boghossiana reguła jest normą, jeśli dostarcza racji/powodu, aby postępować zgodnie $\mathrm{z}$ nią, a nie inaczej. Samo istnienie reguł odnośnie do różnych zachowań takiej wystarczającej racji nie dostarcza. Takich racji dostarczają, zdaniem Boghossiana, tylko normy moralne ${ }^{20}$. Istnienie reguł gry w szachy nie dostarcza wystarczającego powodu, aby w nie grać. Istnienie norm moralnych jest samo wystarczającym powodem, aby postępować zgodnie z nimi. Postępowanie kierowane regułami jest quasi-normatywne, jeśli reguły same nie dostarczają powodu, aby się nimi kierować. Boghossian uważa, że reguły znaczeniowe są quasi-normatywne, czyli normatywne w sposób warunkowy, nieistotny. Za istotną cechę normatywności danej reguły uważa bowiem bezwarunkowy nakaz jej zachowania wynikający z niej samej ${ }^{21}$.

Podobnie J. Hage ${ }^{22}$ przyjmuje, że choć ogólnie rozumiane reguły wiążą się z kierowaniem zachowaniami, to niektóre z nich określają tylko, jakie zachowanie jest poprawne a jakie niepoprawne w sensie zgodności z tymi regułami. Np. zasady gry określają tylko jak należy postępować, aby grać w daną grę, np. w szachy. Powinien je zachowywać ktoś, kto chce grać w ową grę. O normach moralnych nie myślimy w ten sposób. Powinien je zachowywać każdy, a nie tylko ktoś, kto chce postępować moralnie. Nie ma powszechnego oczekiwania aby grać w szachy, podczas gdy istnieje oczekiwanie członków społeczeństwa co do przestrzegania zasad moralnych.

20 P. Boghossian, Rules, Norms and Principles, dz. cyt.,10; P. Boghossian, Is meaning Normative?, dz. cyt., 208.

21 P. Boghossian, Is meaning Normative?, dz. cyt.

22 J. Hage, Separating rules from Normativity, w: Problems of Normativity, Rules and Rule-Following, red. M. Araszkiewicz, P. Banaś, T. Gizbert-Studnicki, K. Płeszka, Springer, Franfurt a. M.-London-New York 2014,13-29. 
Podstawowa cecha wyróżniająca normy (w poszukiwanym w dyskusji nad normatywnością znaczenia sensie) spośród szeroko rozumianych reguł to obligatoryjny charakter norm, którego nie można przypisać wszystkim szeroko rozumianym regułom. Zarówno jednak reguły, jak i normy formułują pewne powinności. Reguły gry w szachy określają jak powinniśmy postępować grając w daną grę, a normy moralne określają jak powinniśmy postępować moralnie. Panuje jednak zgoda, że istnieje zasadnicza różnica pomiędzy siłą formułowanego przez nie zobowiązania. Wydaje się, że za zobowiązaniem przestrzegania norm moralnych stoi jakaś ważniejsza racja niż tylko chęć postępowania w dany sposób. Co jest uzasadnieniem dla powinności wynikającej z samych norm? Co odzwierciedlają czy wyrażają normy? Skąd wynika obligatoryjny charakter norm, którego brak w wypadku zwykłych reguł. W wypadku norm moralnych jako ich rację wskazuje się naturę człowieka i społeczny charakter życia ludzkiego. Czy jest coś w naturze języka, jego konstytucji czy funkcjach, co stanowiłoby wewnętrzną rację dla przestrzegania reguł używania wyrażeń? Czy można istnienie takiej racji wyprowadzić z samego społecznego charakteru języka i jego konwencjonalnego ukonstytuowania

\section{SPOŁECZNY CHARAKTER REGUŁ ZNACZENIOWYCH. KONWENCJE I NORMY}

Ponieważ język jest powszechnie uznawany za system znaków, który ma charakter społeczny, dlatego zasadne wydaje się umieścić zachowania językowe w kategorii społecznych zachowań. Odwołanie się do społecznego charakteru języka pozwala postawić pytanie, czy rozumienie reguł użycia wyrażeń jako konwencji społecznych dostarcza odpowiedzi na pytanie o normatywny charakter znaczenia. Pogląd, że znaczenie językowe jest konwencjonalne, ma swoje miejsce w filozofii od czasów Arystotelesa, jednak w ostatnich dziesięcioleciach stał się na nowo jednym $\mathrm{z}$ dominujących poglądów w kwestii pochodzenia 
reguł użycia wyrażeń. D. Lewis przyjmuje konwencjonalizm niemal za bana1 ${ }^{23}$. Teza Kripkego o normatywności znaczenia zostawia otwarty problem pochodzenia regul znaczeniowych.

Pojawia się pytanie, czy konwencjonalne pochodzenie reguł może dostarczyć wystarczającego wyjaśnienia dla ich normatywnego charakteru? Konwencjonalny charakter reguł związany jest ze sposobem ich społecznego ugruntowania, podczas gdy normatywność odnosi się do ich obligatoryjnego charakteru, do ich zdolności kierowania zachowaniami językowymi. Czy zatem społeczne ugruntowanie i powszechność są wystarczające, aby pojawiło się zobowiązanie do postępowania zgodnie z nimi. Aby odpowiedzieć na to pytanie, należy określić, jakie własności określone są przez konwencjonalny charakter reguł i czy wśród nich są te, które zostały uznane za konstytutywne dla norm.

Ze względu na charakter i zakres zobowiązania, jaki nakładają rożne reguły zachowań społecznych, F. Peter i K. Spiekermann wyróżniają konwencje oraz normy. Konwencje to, według nich, pewne regularności zachowań, ustanowione i podtrzymywane przez system preferencji i oczekiwań w jakieś grupie społecznej w celu koordynacji działań tej grupy ${ }^{24}$.

Normy natomiast są w wyższym stopniu preskryptywne. Formułują one zobowiązanie do ich zachowania. Niedotrzymanie zobowiązania i przekroczenie norm społecznych obłożone jest zawsze jakiegoś rodzaju sankcją, formalną bądź inną. Normy same (choćby ze względu na sankcje) są powodem postępowanie zgodnie z nimi.

Reguły społeczne obowiązują, gdyż pełnią ważną rolę dla społeczeństwa, ta rola stanowi ich rację istnienia $W$ zależności od wagi tej roli dla funkcjonowania społeczeństwa reguły są bardziej lub mniej obligatoryjne. Współczesne wyjaśnienia reguł społecznych

23 D. Lewis, Convention: a Philosophical Study, Harvard University Press, Cambridge MA 1969, 1.

24 F. Peter, K. Spiekermann, dz. cyt., 217-239. 
odwołują się często do teorii racjonalnego wyboru ${ }^{25} \mathrm{i}$ do teorii gier ${ }^{26}$. Podstawowe dwa typy reguł, jakie kierują działaniami jednostek w społeczeństwie wyróżniane w tym kontekście, to reguły koordynacji i reguły kooperacji. D. Lewis definiuje konwencje jako regularności zachowań R członków grupy społecznej w powtarzających się sytuacjach S, gdy spełniają one następujące warunki: 1) Każdy postępuje zgodnie z R, 2) Każdy oczekuje od innych, że będą postępować zgodnie $z \mathrm{R}, 3$ ) Każdy wybiera zachowanie zgodne $\mathrm{z} R$ pod warunkiem, że inni zachowują się zgodnie z R. R jest reguła koordynacji zachowania w sytuacji $\mathrm{S}^{27}$.

Zgodnie $\mathrm{z}$ teorią racjonalnego wyboru jednostka wybiera działanie gwarantujące jak najlepsze osiągnięcie celu jak najmniejszym kosztem. Działania wielu jednostek dokonujących wyboru różnych sposobów osiągnięcia celu wymaga koordynacji. Reguły koordynacji to konwencje w rozumieniu Lewisa.

Normy społeczne są natomiast regułami kooperacji. Są one nie tylko konwencjami, gdyż spełniają warunek koordynacji, ale dodatkowo są regułami kooperacji pomiędzy działającymi jednostkami. Dodatkowy normatywny warunek jest związany z istnieniem sankcji za złamanie norm kooperacji ${ }^{28}$. Sankcje związane $\mathrm{z}$ normami pozwalają zwiększyć atrakcyjność postępowania zgodnie z normą, gdyż narażenie się na sankcje zwiększa koszty osiągnięcia celu na drodze postępowania niezgodnego z regułą. Większość norm społecznych nie posiada sankcji formalnych, ale nieformalne, jak ostracyzm i brak społecznej akceptacji.

Normy społeczne istnieją ze względu na funkcję, jaką pełnią w społeczeństwie. Odzwierciedlają one idee i wartości ucieleśnione

25 Por. C. Bicchieri, The Grammar of Society. The Nature and Dynamics of Social Norms, Cambridge University Press, Cambridge 2006, 31-38. Por. także D. Lewis, dz. cyt., 78.

26 Por. D. Lewis, dz. cyt.

27 Por. Tamże, 42.

28 Por. C. Bicchieri, dz. cyt., 11. 
w strukturze społecznej ${ }^{29}$. Osoba działając ma na uwadze własne preferencje, które obejmują subiektywne cele, środki i warunki, w jakich się znajduje, oraz normy, które są ograniczeniami nałożonymi przez społeczność. Normy stanowią ramy odniesienia dla działania. Złamanie normy narusza kooperację.

Wprowadzenie do teorii racjonalnego wyboru pojęcia zobowiązania, jakie proponuje np. A. Sen, dostarcza dodatkowego elementu motywacji ${ }^{30}$. Pojęcie to pozwala określić jako racjonalne zachowania, które mają na celu nie zwiększenie własnego dobra, ale także poświęcenie dla innych lub działanie dla dobra wspólnego. Dla Sena zobowiązanie jest celem normatywnym w przeciwieństwie do maksymalizacji korzyści jednostki. Dopiero więc reguły, które uwzględniają zobowiązanie, są normatywne. To zatem, co różni w podstawowy sposób reguły i normy, to zawarte w normach zobowiązanie do ich zachowania.

Rozszerzeniem problemu kooperacji jest propozycja wprowadzająca pojęcie wspólnego dobra i intencji zbiorowej ujmującej nie to, „co ja powinienem zrobić”, ale to, „co my powinniśmy zrobić”. Teoria zbiorowej intencji jest proponowana np. przez Searle'a ${ }^{31}$. Takie odniesienie do zbiorowej intencji pozwala na racjonalizację działań wspólnych i podporządkowanie im działań jednostkowych. W takiej sytuacji zobowiązanie jest zbiorowe i cel jest zbiorowy (np. ochrona środowiska). Racjonalne działanie jednostki to działanie na rzecz wspólnie przyjętego celu, jeśli działanie na rzecz tego celu jest racjonalne dla grupy. Taka intencja zbiorowa występująca obok intencji jednostkowych leży u podstawy społecznie przyjmowanego obrazu świata, powszechnych opinii oraz instytucji społecznych, do których Searle zalicza też język.

29 F. Peter, K .Spiekermann, dz. cyt., 220.

30 Np. A. Sen, Rational Choice: Discipline, Brand Name, and Substance, w: Rationality and Commitment, red. F. Peter, H.B. Schmid, Oxford University Press, Oxford 2007, 339-361.

31 J.R. Searle, The Construction of Social Reality, The Free Press, New York 1995. 


\section{ZNACZENIE JĘZYKOWE A KONWENCJE I NORMY}

Podobne jak omówione powyżej wyjaśnienie konwencji i norm $\mathrm{w}$ aspekcie funkcji, jakie pełnią w społeczeństwie, M. Staudacher ${ }^{32}$ wykorzystuje do analizy reguł użycia wyrażeń w aspekcie ich normatywności. Konwencje według niego to społecznie utrwalone regularności zachowań, w postaci standardów lub wzorów postępowania, które narzucają koordynację zachowań w grupie. Postępowanie zgodne $\mathrm{z}$ konwencją jest korzystne dla jednostki i jest zalecane, jeśli inni też zachowują konwencję. Dla zachowania zgodnego z konwencją istnieje jednak dobra alternatywa w zakresie możliwych zachowań. Np. alternatywą dla reguł zachowania przy stole jest jedzenie niezgodne z panującymi regułami, które jednak pozwoli skutecznie zaspokoić głód.

Autor nie uważa jednak, że normy są jedynie konwencjami, które wyposażono w sankcje. Wskazuje na szereg różnic pomiędzy konwencjami a normami, wynikających $\mathrm{z}$ różnicy funkcji, które pełnią one w społeczeństwie, zapewniając odpowiednio koordynację i kooperację w grupie. Normy, podobnie jak konwencje, wprowadzają określony wzór działania. Są jednak prospektywne, czyli odwołują się do powinności, zobowiązania, mówią jak powinno się postępować. W wypadku normy nie musi istnieć dobra alternatywa zachowania, a w wypadku norm moralnych jej po prostu nie ma. Normy w przeciwieństwie do konwencji wymagają odzwierciedlania w strukturze społecznej. Wymagają kogoś, kto ma ich przestrzegać, kogoś kto nadzoruje ich przestrzeganie, kogoś kto stosuje sankcje itp.

Koordynacja zachowań, która jest funkcją norm społecznych, nie dotyczy tylko działań fizycznych, ale także sposobu widzenia świata, uzgadniania opinii, klasyfikacji zdarzeń itd. Jest to narzędzie pewnego ujednolicenia działań i intencji. Taka koordynacja

32 M. Staudacher, Use theories of meaning, between conventions and social norms, University of Amsterdam, Amsterdam 2010. 
jest podstawą kooperacji. Wymagania stawiane przez normy kierują nasze preferencje w kierunku współdziałania $\mathrm{z}$ innymi. Funkcją norm społecznych jest kształtowanie sądów i przekonań. Stają się one motywami działania.

Czy zatem znaczenie jest normatywne? Czy reguły użycia są tylko konwencjonalne czy normatywne? Samo przyjęcie znaczeń jako konwencji społecznych nie rozwiązuje problemu normatywności znaczenia. Znaczenie spełnia bowiem niektóre warunki stawiane normom społecznym, a inne konwencjom.

Reguły użycia wyrażeń są regułami kooperacji, leżą u podstaw współdziałania dla osiągnięcia wspólnego celu, jakim jest choćby komunikacja językowa. Znaczenie leży u podstaw unifikacji naszego widzenia świata, kategoryzacji, wiedzy itd. Można też twierdzić, że włączając się w społeczność mówiącą danym językiem, przyjmujemy pewne zobowiązanie wynikające $z$ reguł kooperacji, a mianowicie, że będziemy używać wyrażeń zgodnie $z$ ich znaczeniem.

Jeśli przyjmiemy, że przypisywanie wyrażeniom określonych znaczeń jest sprawą konwencji, to istnienie takiej konwencji budzi uzasadnione oczekiwanie zgodnego $\mathrm{z}$ nią zachowania. W wypadku konwencjonalnych reguł etykiety istnieje alternatywa zachowania równie skuteczna, choć może społecznie nieakceptowana. Jednak w wypadku języka, użycie wyrażenia niezgodnie z jego znaczeniem, wbrew regułom, czyni komunikację językową nieskuteczną. Nie ma zatem dobrej alternatywy w ramach danego języka do użycia wyrażeń zgodnego $\mathrm{z}$ ich znaczeniem, podobnie jak w wypadku norm. Reguły te obowiązują jednak tylko w grupie osób posługujących się danym językiem. Użycie wyrażeń zgodne $z$ regułami jest korzystne dla jednostki, jeśli inni też mówią danym językiem i z tego powodu jest ono zalecane. Podobnie jak w wypadku konwencji stosowanie wyrażeń zgodnie $\mathrm{z}$ ich znaczeniem jest korzystne dla obu stron.

Poprawne użycie jest też w pewnym sensie nadzorowane instytucjonalnie - istnieją słowniki, specjaliści, nauczyciele itd. Istnieje też 
ocena negatywna w wypadku niepoprawnego użycia i pozytywna w wypadku poprawnego, co może być pewnym rodzajem sankcji.

M. Staudacher wysuwa jeszcze inny argument na rzecz normatywności znaczenia. Niepoprawne użycie może być spowodowane pomyłką co do znaczenia. Jeśli, twierdzi autor, ktoś może popełnić pomyłkę i użyć wyrażenie niezgodnie z jego znaczeniem, to jest odpowiednia norma społeczna związana $\mathrm{z}$ tym znaczeniem. Zdaniem autora, fakt, że możemy popełniać pomyłki co do znaczenia, wskazuje, $\dot{z}$ istnieją normy znaczeniowe ${ }^{33}$.

Jak wynika z powyższego, znaczenie konwencjonalne ma niektóre cechy norm, choć nie wszystkie. Aby określić status reguł językowych, Staudacher wprowadza pojęcie konwencji normatywnych ${ }^{34}$. Konwencje normatywne to reguły, które posiadają pewne cechy konwencji a pewne cechy norm. Są one konwencjami, ponieważ zachowanie zgodne $\mathrm{z}$ regułami jest korzystne, jeśli inni też zachowują sie zgodnie $\mathrm{z}$ nimi. Zachowanie zgodne $\mathrm{z}$ regułami jest zalecane $\mathrm{w}$ danej grupie i jest ono dla obu stron korzystne. Istnieje też dobra alternatywa dla zachowań zalecanych konwencją ( np. jedząc niezgodnie z zasadami etykiety, zaspokoimy skutecznie zaspokoimy głód, czyli osiągniemy główny cel posiłku), tej cechy reguły znaczeniowe, jak wykazała nasza analiza, nie wykazują.

Posiadają one jednak także cechy norm. Jeśli konwencje są mocno zakorzenione w społeczeństwie, to zachowanie zgodne z konwencją staje się nie tylko rekomendowane, ale i oczekiwane. To oczekiwanie jest związane z żądaniem zachowania konwencji. Takie konwencje formułują żądania postępowania zgodnego $\mathrm{z}$ regułą. Jeśli utrwalone zachowanie staje się konwencją zakorzenioną w społeczności, to staje się ono konwencją normatywną.

W wypadku znaczenia wyrażeń zachodzi płynne przejście pomiędzy konwencjami a konwencjami normatywnymi i normami.

33 Tamże, 60.

34 Tamże, 246. 
Np. ktoś wymyśli neologizm, ustanawiając nowe użycie wyrażenia o określonym znaczeniu. Na początku nie ma żadnego oczekiwania, aby tak używać tego wyrażenia. Jeśli jednak takie użycie się rozpowszechni i urwali oraz stanie się konwencją, to takie użycie będzie korzystne i zalecane. Wraz z tym pojawi się oczekiwanie danego sposobu użycia, związane $\mathrm{z}$ istnieniem konwencji, a zatem i zobowiązanie lub powinność używania wyrażeń zgodnego z regułą. Takie zachowanie wzmacnia regułę i staje się ona konwencją normatywną a nawet normą ${ }^{35}$. W wypadku norm pojawia się element sankcji, w wypadku znaczenia - ocena, że dane użycie jest niepoprawne. Jeśli ktoś ma prawo powiedzieć, że dane użycie jest niepoprawne, to jest to rodzaj negatywnej oceny zachowania, a więc pewien rodzaj sankcji.

Wskazane powyżej zobowiązanie do odpowiedzi na społeczne oczekiwanie, związane z panującą regułą, daje niepełny obraz normatywnego charakteru reguł językowych. U podstaw reguł znaczeniowych leżą nie tylko konwencje społeczne.

\section{DWA UWARUNKOWANIA NORMATYWNOŚCI ZNACZENIA}

J. Searle wyodrębnił dwa typy reguł społecznych - reguły regulatywne i reguły konstytutywne - podając jako przykład tych pierwszych, reguły zachowania przy stole, jako przykład tych drugich reguły gry w szachy czy regułę ustanawiającą odpowiedni kawałek papieru banknotem o określonym nominale. Reguly konstytutywne ustalają nowe fakty społeczne. Ogólna postać reguły konstytutywnej ma postać: X jest uważane za $Y$ w kontekście $C^{36}$.

Searle wskazuje, że podobnie u podstaw języka leżą reguły konstytutywne. To one konstytuują język jako system znaków. Co jednak dokładnie one konstytuują? Konstytuują dźwięki bądź napisy, jako

35 Tamże, 248.

36 Por. J. Searle, Czynności mowy. Rozważania z filozofii języka, z ang. tłum. B. Chwedeńczuk, Instytut Wydawniczy Pax, Warszawa 1987, 51. 
wyrażenia językowe. Istnieje jednak zasadnicza różnica pomiędzy regułami gry w szachy a regułami użycia wyrażeń. Ruchy pionków mają tylko wewnętrzne znaczenia, odniesione do elementów gry. One nie odnoszą się do niczego poza samą grą. Wyrażenia języka posiadają dodatkowo znaczenia, które wyposażają je w treści o świecie zewnętrznym. Są nie tylko powiązane wzajemnymi wewnątrzsystemowymi relacjami, ale także pozostają w relacji do świata istniejącego poza systemem znaków. Te zewnętrzne relacje do świata są podstawą związków wewnątrz systemu. W innym kontekście stwierdzenie to jest banalne. W dyskusji nad normatywnością znaczenia, gdy zastaje to pomijane, traci się z oczu fakt, że celem użycia języka jest mówienie o świecie a reguły znaczeniowe mają na celu zachować właśnie tę funkcję języka. Te związki ze światem, są implicite zawarte w regułach użycia. Reguły konstytutywne, o których mówi Searle, ustalają związek wyrażenia ze znaczeniem, ale nie konstytuują samych znaczeń. Przypisują one daną treść wyrażeniu, ale to struktura świata jest źródłem tej treści, a nie reguły użycia. Reguły użycia odzwierciedlają nie tylko konwencjonalne związki zewnętrznej formy wyrażeń $z$ ich znaczeniami, ale i relację języka do świata związaną z jego funkcją reprezentacji świata.

Znaczenie to treść przedmiotowa, która jest na mocy reguły konstytutywnej łączona z terminem lub wyrażeniem. Treść ta jest jednak niezależna od żadnych reguł, czy to rozumianych jako konwencje, czy to jako reguły konstytucyjne. Reguły semantyczne to reguły posługiwania się wyrażeniami, chroniące zachowanie przypisanej im treści. Znaczenia odzwierciedlają strukturę i relacje świata, tego, co ludzie w nim wyodrębniają, rozpoznają i w różnoraki sposób ujmują poznawczo, zarówno w aspekcie fizykalnym, jak społecznym i mentalnym. Przedmiot, relacja społeczna, różnica, idea, coś, co jest w jakikolwiek sposób dostrzeżone i wyodrębnione, co następnie, jest społecznie rozpoznawalne, staje się treścią wyrażenia. Forma wyrażenia jest konstytuowana społecznie przez reguły konstytutywne, jednak sama treść jest zewnętrzna i w stosunku do aktu konstytucji 
pierwotna. Ta treść powinna być zachowana przez użyte wyrażenia, aby można było za pomocą języka mówić o świecie.

Istnieje zatem drugi aspekt normatywności znaczenia, związany z jego funkcją reprezentacji całego bogactwa ujmowanych przez społeczność zjawisk. Znaczenia ustalają standardy treści, które powinny być łączone z wypowiedziami danych wyrażeń, bądź standardowe role, jakie elementy języka pełnią w wyrażaniu treści. Dopiero dla takich wyposażonych w znaczenia wyrażeń ustalane są reguły użycia, które nakazują właśnie przypisywanie określonej treści do określonych wyrażeń i posługiwania się wyrażeniami z zachowaniem tej treści. Ten wymiar znaczenia leży u podstaw językowych działań człowieka w świecie i opartego na zachowaniach językowych współdziałania $z$ innymi. Podobnie jak normy moralne narzucaja pewien rodzaj zachowań oczekiwanych w społeczeństwie, tak reguły znaczeniowe zapewniają podstawę współdziałania członków społeczności w świecie, który podlega pod wpływem tego działania ciągłym przemianom. Elementami wzajemnego uzgadniania i oddziaływania są więc nie tylko członkowie społeczności, dla których świat stanowi tło, ale członkowie społeczności i świat jako aktywny i dynamiczny uczestnik gry i współautor reguł kooperacji.

Konwencje językowe utrwalają reguły konstytutywne nadające postaciom dźwięków charakter wyrażeń języka i przypisują do nich odpowiednie treści. System reguł językowych jako całość ma za zadanie adekwatnie reprezentować świat jak najszerzej rozumianego ludzkiego doświadczenia i działania. Jeśli ta rola nie jest spełniona, język jest niefunkcjonalny, nie można mówić w nim adekwatnie, ani prawdziwie o świecie.

Posługiwanie się językiem jest postępowaniem zgodnym $\mathrm{z}$ regułami, które z jednej strony mają charakter reguł społecznych, $z$ drugiej zaś są odniesione do świata przedmiotowego, który jest w języku reprezentowany. Oba elementy odzwierciedlają się w naturze reguł użycia wyrażeń. Element przedmiotowy wynikający z funkcji reprezentacji jest istotnie normatywny. Sam element konwencjonalny 
nadawałby regułom językowym status jedynie taki, jaki mają reguły gry w szachy. Przy pomocy języka nie można by mówić o świecie zewnętrznym. Jeśli nie używamy wyrażeń zgodnie z ich znaczeniami, nie używamy danego języka, jeśli pominiemy związki ze światem, nie możemy mówić o czymś. Aby powiedzieć coś o czymś, musimy użyć wyrażeń, które to właśnie znaczą. Chcąc wyrazić określone treści, powinniśmy użyć wyrażeń o właściwych znaczeniach. Sama chęć poprawnego stosowania reguł semantycznych nie jest źródłem powinności, jak twierdzi Boghossian, nie ona też jest powodem, dla którego powinno się poprawnie używać wyrażeń. To, jak powinniśmy wyrazić określone treści, wynika ze znaczenia.

Podobnie, jak w wypadku norm moralnych, nie ma dobrej alternatywy dla użycia wyrażenia zgodnie z jego znaczeniem. Alternatywą nie jest przecież używanie dźwięków bez znaczenia, ani też posługiwanie się innym językiem (który też ma reguły, jest to więc przejście od jednego systemu reguł do drugiego). Powinność poprawnego użycia (czyli z zachowaniem znaczenia) wynika więc z samej natury wypowiedzi językowej, co czyni normatywność znaczenia jego wewnętrzną cechą. Wyrazić myśli o określonej treści, to użyć odpowiedniego znaczenia, inaczej dana treść nie zostanie wyrażona. Podobnie, jak powinność postępowania moralnego wynika $\mathrm{z}$ tego, że istnieją normy moralne, które odzwierciedlają moralną naturę człowieka, tak wyrażeń językowych używamy ze względu na przypisane im znaczenia, które wnoszą do wypowiedzi określoną treść wynikającą z relacji języka do świata.

Można więc podsumować: społeczne ugruntowanie języka nadaje normatywny charakter regułom znaczeniowym ze względu na zobowiązanie, jakie względem zachowań członków społeczności nakłada ugruntowana społecznie konwencja. Drugim czynnikiem, decydującym o normatywności znaczenia, jest związek języka ze światem zewnętrznym, który nakłada standardy gwarantujące wyrażanie treści przedmiotowych. 


\section{ZAKOŃCZENIE}

W artykule zostały podjęte kwestie: $\mathrm{w}$ jakim sensie można mówić o normatywności znaczenia, co owa normatywność oznacza i czym można ją uzasadnić. Zostały przedyskutowane argumenty na rzecz poglądu, że za normatywne uznajemy takie reguły, które mają wewnętrzną zdolność formułowania powinności określonego działania. Zostało też pokazane, że społeczne utrwalenie reguł rodzi oczekiwanie, a za nim zobowiązanie do ich przestrzegania. Jednak siła tego zobowiązania zależy nie tylko od społecznej konstytucji regul. Status zobowiązania, jakie formułują reguły języka, jest inny od tego, jakie formułują np. reguły gry w szachy. Ta różnica wynika z faktu, że język pełni funkcję społecznej reprezentacji świata i ta właśnie funkcja jest wewnętrznym źródłem jego normatywności. Ten ostatni aspekt normatywności został jednak tylko zasygnalizowany i wymaga szerszej dyskusji oraz dalszych uzasadnień.

\section{BIBLIOGRAFIA}

Bicchieri C., The Grammar of Society. The Nature and Dynamics of Social Norms, Cambridge University Press, Cambridge 2006.

Boghossian P., Rules, Norms and Principles: A Conceptual Framework, w: Problems

of Normativity, Rules and Rule-Following, red. M. Araszkiewicz, P. Banaś,

T. Gizbert-Studnicki, K. Płeszka, Springer, Franfurt a.M.- London- New York, 2014, 3-11.

Boghossian P., Is Meaning Normative?, w: Philosophy-Science-Scientific Philosophy. Main Lectures and Colloquia of GAP. 5, Fifth International Congress of the Society for Analytical Philosophy, red. Ch. Nimtz, A. Beckermann, Mentiz, Paderborn 2003, 205-218.

Boghossian P., The Rule-Following Considerations, Mind 98(1989), 507-549.

Brożek B., Pojęcie normatywności, w: Fenomen normatywności, red. A. Brożek, B. Brożek, J. Stelmach, Copernicus, Kraków 2013, 19-44.

Hage J., Separating rules from Normativity, w: Problems of Normativity, Rules and Rule-Following, red. M. Araszkiewicz, P. Banaś, T. Gizbert-Studnicki, K. Płeszka, Springer, Franfurt a.M.- London- New York, 2014, 13-29. 
Hattiangadi A., Some more thoughts on semantic oughts: a reply to Daniel Whiting, Analisys 69(2009)1, 54-63.

Hattiangadi A., Oughts and Thoughts: Rule-Following and the Normativity of Content, Oksford University Press, Oxford 2007.

Hattiangadi A., Is meaning normative?, Mind and Language 21(2006), 220-240.

Korsgaard Ch. M., The Sources of Normativity, Cambridge University Press, Cambridge 1996.

Kripke S., Wittgenstein o regułach i jezyku prywatnym, tłum z ang. K. Posłajko, L. Wroński, Aletheia, Warszawa 2007.

Lewis D., Convention: a Philosophical Study, Harvard University Press, Cambridge MA, 1969.

Peter F., Spiekermann K., Rules, Norms and Commitments, w: The Sage Handbook of The Philosophy of Social Science, red. I.C. Jarvie, J. Zamora-Bonilla, Sage, London, 217-23.

Sen A., Rational Choice: Discipline, Brand Name, and Substance, w: Rationality and Commitment, red. F. Peter, H.B. Schmid, Oxford University Press, Oxford 2007, 339-361.

Searle J.R., The Construction of Social Reality, The Free Press, New York 1995.

Searle J. R., Czynności mowy. Rozważania z filozofii jezzyka, tłum. z ang. B. Chwedeńczuk, Instytut Wydawniczy Pax, Warszawa 1987.

Staudacher M., Use theories of meaning, between conventions and social norms, University of Amsterdam, Amsterdam 2010.

Whiting D., The Normativity of Meaning Defended, Analysis 67(2007)2,133-140.

\section{RULES OF USE AND THE NORMATIVITY OF MEANING}

Abstract. This article focuses on some issues in the contemporary debate about the normativity of meaning initiated by Kripke's famous book. The core of this debate concerns the relationship between the normativity of meaning and the correctness conditions of language use, but fails to deal with the concept of normativity itself.

This article aims to discuss this neglected problem, and considers issues such as: What does it mean that rules are normative? How are we to understand the concept of a "norm", and what distinguishes norms from other types of rules? What is the justification of the normative character of the rules governing the use of linguistic expressions?

To begin, Kripke's thesis of meaning normativity is briefly presented together with its main line of criticism and a defence of this idea. Then various proposals for understanding the concepts of "rules" and "norms" are considered, and the basic features of these two concepts are identified. Next, the idea that the rules for the use of linguistic expressions are socially determined is examined, and the social dimension of language is considered as 
a possible justification for the normativity of meaning. The last issue considered concerns the relationship between the socially established rules for the use of linguistic expressions and their meaning, which has a referential component. Meaning is connected with content and as such it is not only conventional, but also constituted by a representative function of language.

Finally, it is suggested that there are two dimensions of the normativity of meaning: a social dimension, which is granted on normative conventions, and a non-social dimension related to the representative function of language.

Keywords: linguistic meanings, rules, norms, conventions, normativity, use of linguistic expressions

\author{
JANINA BUCZKOWSKA \\ janina.buczkowska@uksw.edu.pl \\ Uniwersytet Kardynała Stefana Wyszyńskiego w Warszawie, Instytut Filozofii \\ Wóycickiego 1/3, 01-938 Warszawa
}

DOI: 10.21697/spch.2017.53.4.01 